\title{
The effect of number of lactation and concentrate level on feed intake and performance of dairy cows
}

\author{
S Mack, GU Lang, H Steingass, A Susenbeth, W Drochner \\ Institute of Animal Nutrition, University of Hohenheim, 70593 Stuttgart, Germany
}

Feed intake level and performance of cows increase with age. Especially primiparous cows can be regarded as "trainees" with limited feed intake capacity hence having more difficulties to match energy requirement.

In the present study initially 44 Holstein Friesian cows were used in a long-term feeding experiment over 3 complete lactations. After first calving, cows were randomly allotted to 2 groups : Group 1 (high) receiving concentrate according to milk yield; Group 2 (low) was fed $80 \%$ (wk 3-8), $60 \%$ (wk 9-15), $40 \%$ (wk 1629) and $30 \%$ (>wk 29) of their demand with an average concentrate allowance of $50 \%$ of group 1. Concentrate allowance was adjusted weekly for each cow according to milk yield.

The roughage consisted (on dry matter -(DM)basis) of $50 \%$ hay and $50 \%$ grass silage (9 MJ ME/kg DM) throughout the experiment. Cows were kept in a loose-house stable where daily intake of roughage and concentrate was recorded automatically and continuously for each cow. In addition, individual liveweight and milk yield were measured daily. Mean daily values over the whole lactation for DM-intake, liveweight, milk yield and energy balance (ME-intake minus ME requirement) are given in the table.

Intake, liveweight and milk yield were generally increasing with age. In both concentrate groups differences in total intake, liveweight and milk yield were significant between 1 st and 2nd but not between 2nd and 3rd lactation. Under reduced concentrate feeding scheme a general increase in roughage intake but a decrease in total intake, milk yield, liveweight and energy balance could be observed in all lactations. The impact of concentrate level on roughage intake resulted in a substitution rate of $0.38,0.37$ and 0.76 in 1 st, 2nd and 3rd lactation, respectively. At low concentrate allowance a steady and significant increase in roughage intake was found with increasing number of lactation.

It can be concluded, that cows fed high concentrate levels tend to approach their maximum feed intake at an earlier age. Although primiparous cows have a higher energy requirement for additional growth, the level of concentrate has a similar effect on milk yield and energy balance in all lactations.

\begin{tabular}{|c|c|c|c|c|c|c|c|}
\hline \multirow{2}{*}{$\begin{array}{l}\text { Lact. } \\
\mathrm{N}^{\circ}\end{array}$} & \multirow{2}{*}{$\begin{array}{l}\text { Concentr } \\
\text { allowance }\end{array}$} & \multicolumn{3}{|c|}{ Feed intake $(\mathrm{kg} \mathrm{DM} / \mathrm{d})$} & \multirow{2}{*}{$\begin{array}{l}\text { Livewght } \\
\quad(\mathrm{kg})\end{array}$} & \multirow{2}{*}{$\begin{array}{l}\text { Milk yield } \\
\text { (kg/lact.) }\end{array}$} & \multirow{2}{*}{$\begin{array}{l}\text { Energy } \\
\text { balance }\end{array}$} \\
\hline & & Roughage & Concentr & Total & & & \\
\hline \multirow[t]{2}{*}{1} & high $(n=25)$ & $11.4^{\mathrm{aA}}$ & $5.4^{\mathrm{aA}}$ & $16.8^{\mathrm{aA}}$ & $565^{\mathrm{aA}}$ & $6000^{\mathrm{aA}}$ & $+12.8^{\mathrm{aA}}$ \\
\hline & $\operatorname{low}(n=19)$ & $12.5 \mathrm{a} \alpha$ & $2.5^{\mathrm{b} c}$ & $15.0^{\mathrm{b} \alpha}$ & $546^{b \alpha} \alpha$ & 5344 ba & $-0.3^{\mathrm{b} \alpha}$ \\
\hline \multirow[t]{2}{*}{2} & high $(n=13)$ & $12.7 \mathrm{aAB}$ & $6.7^{\mathrm{aB}}$ & $19.4 \mathrm{aB}$ & 634 ав & $7006^{a B}$ & $+21.7^{\mathrm{aA}}$ \\
\hline & low $(n=18)$ & $14.0 \mathrm{a} \beta$ & $3.2^{\mathrm{bB}}$ & $17.2^{\mathrm{b} \beta}$ & $604 \mathrm{a} \beta$ & $6358 \mathrm{a}$ & $+0.7 \mathrm{~b} \alpha$ \\
\hline \multirow[t]{2}{*}{3} & high $(n=8)$ & $12.6^{\mathrm{aB}}$ & $7.1^{\mathrm{aB}}$ & $19.7 \mathrm{aB}$ & $648^{\mathrm{aB}}$ & $7518^{a 8}$ & $+13.8^{\mathrm{aA}}$ \\
\hline & low $(n=11)$ & $15.5^{\mathrm{by}}$ & $3.3^{\mathrm{b} \beta}$ & $18.8^{\mathrm{a} \beta}$ & $628 \mathrm{a \beta}$ & $6682^{\mathrm{a} \beta}$ & $+7.8 \mathrm{a} \alpha$ \\
\hline
\end{tabular}

Means with unlike signs differ $(P<0.05)$ : a between concentrate levels within lactations ; ${ }^{A}$ between lactations at high concentrate level ; $\alpha$ between lactations at low concentrate level 